\title{
Johann Christian Reil (1759-1813) who first described the insula
}

\author{
IIlhan Bahşi ${ }^{1}$ • Saliha Seda Adanir ${ }^{1} \cdot$ Şeyma Karatepe ${ }^{2}$ \\ Published online: 28 May 2020 \\ (C) Springer-Verlag GmbH Germany, part of Springer Nature 2020
}

\section{His life}

The German physician, anatomist, psychiatrist, and physiologist Johann Christian Reil (Fig. 1) was born on 20 February 1759 in Rhaude, Ostfriesland [1]. Reil was the biggest of five brothers. He was a son of a Lutheran pastor in the small East Friesland town of Rhaude. His father's name was Johann Julius Friedrich Reil and his mother's name was Anna Jansen-Streng [1-3]. In 1788, he had married Johanna Wilhelmine Levaux, who is a daughter of a wealthy and reputable Halle family, and he had two sons and four daughters [3].

His first education was near Norden, a small town on the sea. In 1779, he began medical education at the University of Göttingen. In 1780, he moved to the University of Halle. Two years later, he graduated with his thesis named Tractatus de polycholia on the biliary diseases. He took lessons from the teacher such as Phillip Friedrich Theodor Meckel (17561803) and the clinician Johann Friedrich Gottlieb Goldhagen (1742-1788) [1].

In 1782 and 1783, Reil went to Berlin to obtain Cursus anatomicus, a certificate to become a doctor in Prussia [3].

Șeyma Karatepe

karatepe_seyma@hotmail.com

İlhan Bahşi

dr.ilhanbahsi@gmail.com

Saliha Seda Adanir

seda.adnr93@gmail.com

1 Department of Anatomy, Faculty of Medicine, Gaziantep University, TR-27310 Gaziantep, Turkey

2 School of Medicine, Gaziantep University, Gaziantep, Turkey

\section{His works}

In 1975, he founded Archiv für die Physiologie, the first scientific journal on physiology in Germany. Physics, chemistry, histology, biology, and comparative anatomy studies were presented in this journal [1]. Following the publication of Reil's article in 1808, the psychiatry term began to be accepted. The most important issue for Reil was the prevention of the stigmatization of patients hospitalized with a mental illness [2]. 
Reil was a valuable physician for his understanding and care of mental illnesses. Another important issue for him was to train paramedical personnel who could meet unmet medical needs in the countryside [1]. Reil who gave the discipline of psychiatry its name has contributed to medicine, physiology, and psychiatry with his studies on neuroanatomy, medicine, treatment, and mental illnesses [2]. Reil was the first person to describe the white fiber tract now called the arcuate fasciculus and the locus coeruleus [4].

In 1796, he published Exercitationum anatomicarum fasciculus primus de structura nervorum, tribus tabulis aeneis illustratus (First Volume of Anatomical Practice: On the Structure of Nerves) (Fig. 2). This study was about the nerves. In the book, he also mentioned the insula. Although the nerves were shown with illustrations, the insula was mentioned only in the text. In these illustrations, some nerves of the peripheral nervous system, the optic nerve and the optic chiasma, have been shown (Fig. 3 and Cover) [5].

Over time, the insula was named with many different names such as the central lobe, the fifth lobe of the brain,

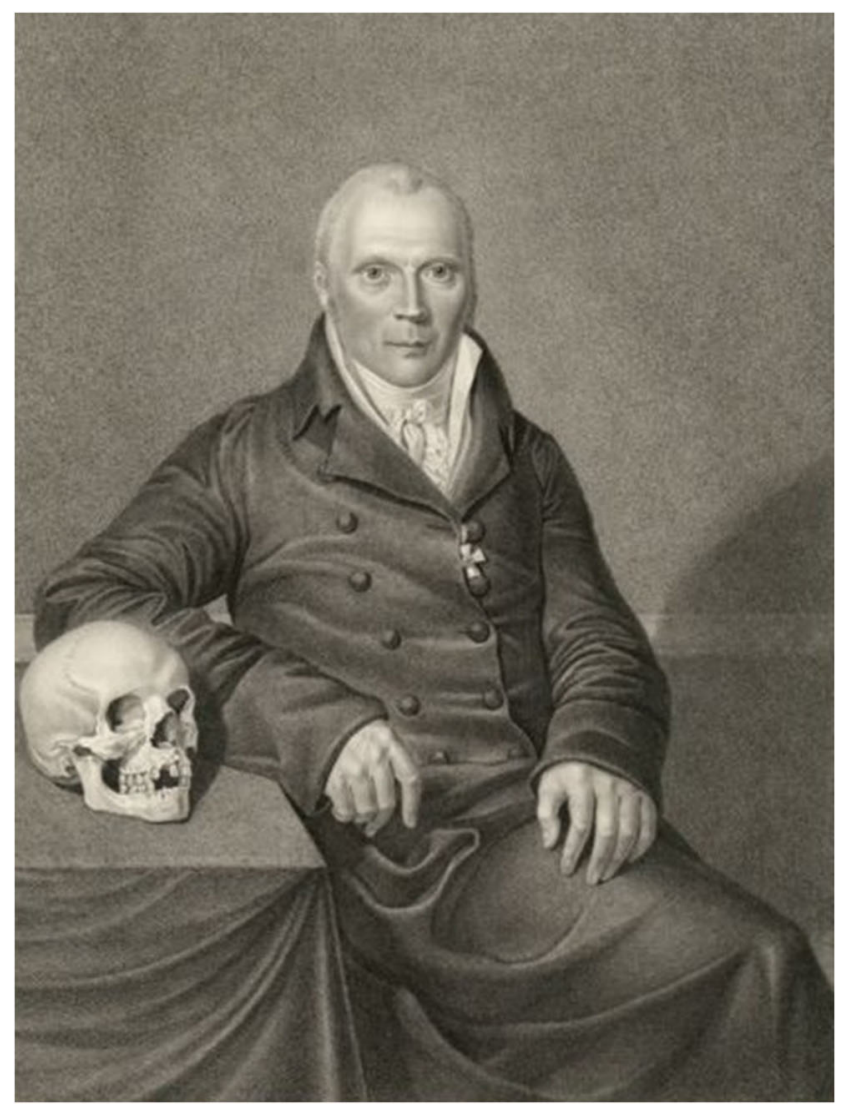

Fig. 1 Johann Christian Reil, which can be found at https:/en.wikipedia. org/wiki/Johann Christian Reil\#/media/File:Johann Christian Reil (1811).jpg which can be found at Accessed 03.05.2020 intersylvian convolutions, and intralobular gyri. In the 1st edition of Gray's Anatomy (1858), Henry Gray named this region as the island of Reil [6].

\section{Related eponyms}

There are some eponyms with name of Johann Christian Reil Reil's finger: Digitus mortuus or Raynaud syndrome Island of Reil: the insula of the cerebral cortex Reil's triangle: trigone of lateral lemniscus Sulcus of Reil: circular sulcus of the insula

\section{Conclusions}

Reil should be remembered because he is a founder of psychiatry, a good neuroanatomist, a prominent medical educator and administrator, and a pioneer in scientific medical physiology and because of his contributions to today's knowledge.

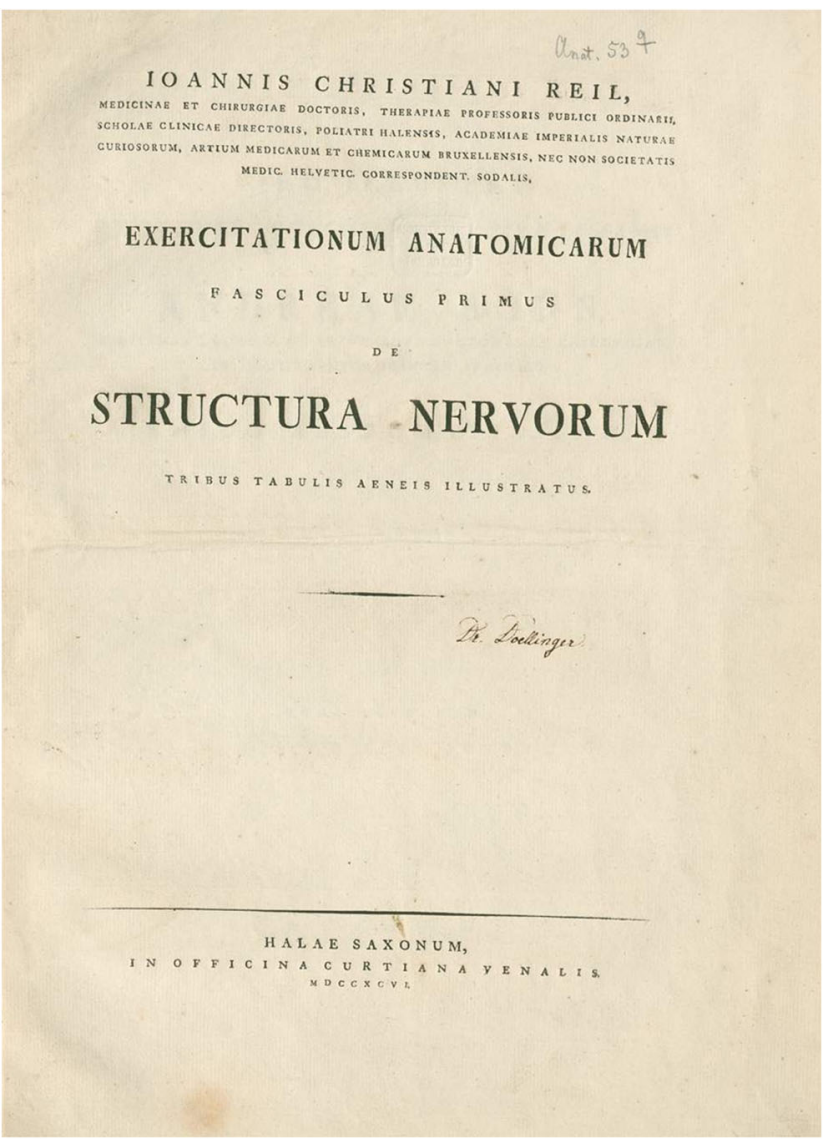

Fig. 2 Title page of Exercitationum anatomicarum fasciculus primus de structura nervorum, tribus tabulis aeneis illustratus 


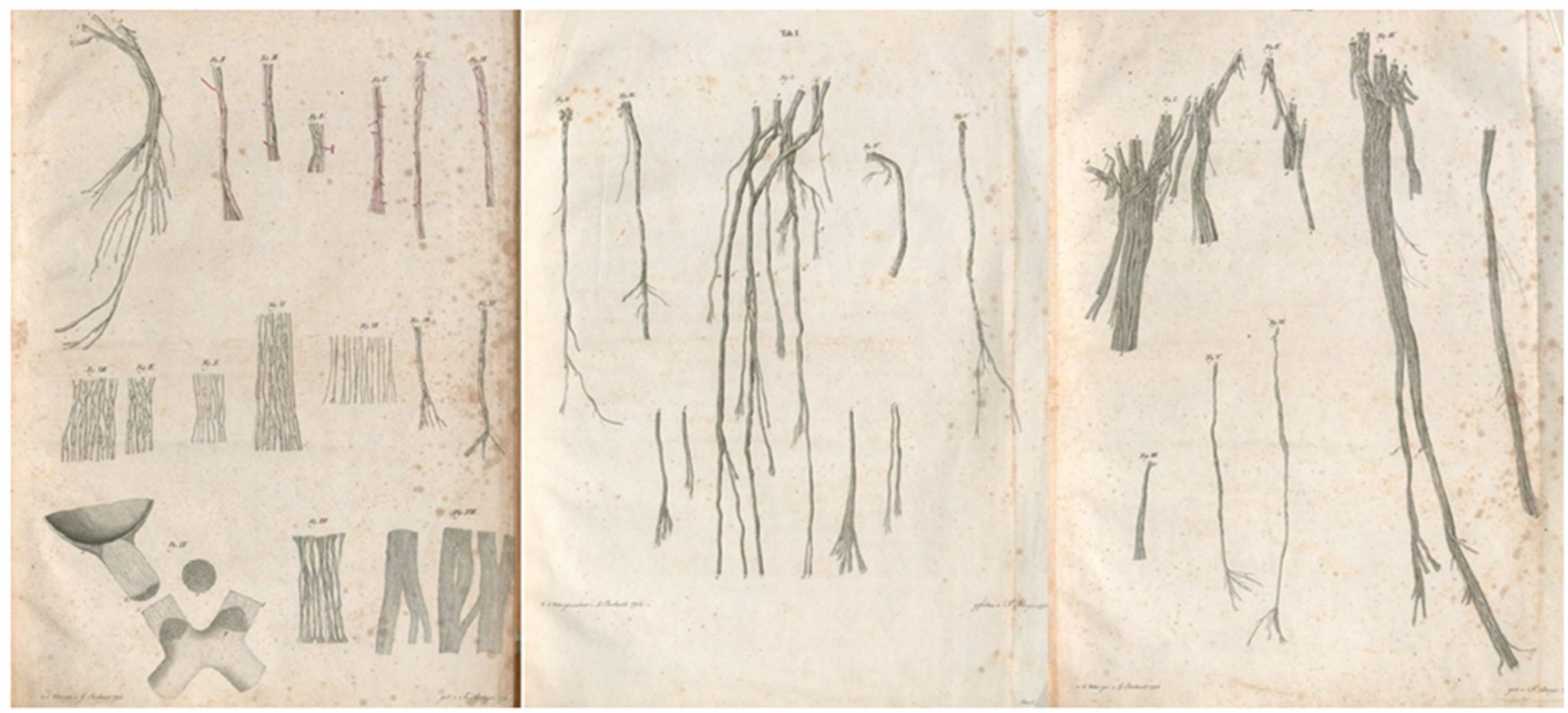

Fig. 3 and Cover Some illustrations in Exercitationum anatomicarum fasciculus primus de structura nervorum, tribus tabulis aeneis illustratus

\section{Compliance with ethical standards}

Conflict of interest None.

\section{References}

1. http://www.whonamedit.com/doctor.cfm/1176.html. Accessed 02 . 05.2020

2. Kaplan RM (2012) Johann Christian Reil and the naming of our specialty.
3. Binder DK, Schaller K, Clusmann H (2007) The seminal contributions of Johann-Christian Reil to anatomy, physiology, and psychiatry. Neurosurgery 61:1091-1096

4. https://en.wikipedia.org/wiki/Johann_Christian_Reil. Accessed 02. 05.2020

5. Reail JC (1796) Exercitationum anatomicarum fasciculus primus de structura nervorum, tribus tabulis aeneis illustratus

6. Fusar-Poli P, Howes O, Borgwardt S (2009) Johann Cristian Reil on the 200th anniversary of the first description of the insula (1809). BMJ Publishing Group Ltd

Publisher's note Springer Nature remains neutral with regard to jurisdictional claims in published maps and institutional affiliations. 